\title{
Regulation of insulin-like growth factor-binding protein-3 ternary complex in feline diabetes mellitus
}

\author{
M S Lewitt ${ }^{1,3}$, S J Hazel ${ }^{1}$, D B Church², A D J Watson², \\ $S$ E Powell ${ }^{2}$ and $K$ Tan $^{1}$ \\ ${ }^{1}$ Department of Medicine, The University of Sydney, New South Wales, Australia \\ ${ }^{2}$ Department of Veterinary Clinical Sciences, The University of Sydney, New South Wales, Australia \\ ${ }^{3}$ Department of Molecular Medicine, Karolinska Institute, Stockholm, Sweden \\ (Requests for offprints should be addressed to M S Lewitt, Department of Molecular Medicine, Unit for Endocrinology and Diabetes, Karolinska Institute, \\ S 17176, Stockholm, Sweden; Email: moira@enk.ks.se)
}

\begin{abstract}
The $140 \mathrm{kDa}$ ternary complex of insulin-like growth factor-binding protein-3 (IGFBP-3), IGFs and an acidlabile subunit (ALS) has previously been shown to be decreased in diabetes mellitus in humans and rats. We have studied IGF-I levels and ternary complex formation in normal and diabetic cats. Total IGF-I concentrations, measured by RIA using des(1-3)-IGF-I as tracer were ( \pm S.E.M.) $54 \pm 13 \mathrm{nmol} / 1$ in eight normal and $227 \pm 57 \mathrm{nmol} / 1$ in eight diabetic cats $(P<0 \cdot 01)$. The size-distribution of IGFBPs in the cat circulation was determined by incubation with ${ }^{125}$ I-IGF-II and Superose 12 chromatography. In normal animals $26 \pm 2 \%$ of the ${ }^{125}$ I-IGF-II were in a $140 \mathrm{kDa}$ form compared with $48 \pm 5 \%$ in diabetic cats $(P<0 \cdot 01)$. When samples from normal and diabetic animals were co-incubated $52 \pm 3 \%$ were at $140 \mathrm{kDa}$. A similar shift was seen when normal cat and normal human serum were co-incubated. A 2-fold increase in the $140 \mathrm{kDa}$ form in diabetic cats was con-
\end{abstract}

firmed first by size-fractionating samples and then performing a ligand-binding assay with ${ }^{125}$ I-IGF-I or -II and charcoal separation. SDS-PAGE and Western ligand blotting demonstrated a $45 \mathrm{kDa}$ doublet (presumably IGFBP-3) and 30-35 kDa forms. There were no apparent differences between normal and diabetic profiles on SDSPAGE, suggesting that a proportion of IGFBP-3 which circulates 'free' in normal cats forms a ternary complex in the diabetic circulation. We conclude that (i) in contrast to humans and rats, ALS is the limiting factor for ternary complex formation in normal cats, (ii) ALS concentrations increase in feline diabetes mellitus and, by promoting ternary complex formation, this leads to an increase in total IGF-I concentrations, and (iii) total IGF-I concentrations may not be reliable in the diagnosis of acromegaly in diabetic cats.

Journal of Endocrinology (2000) 166, 21-27

\section{Introduction}

Previous studies have shown that insulin-like growth factor-I (IGF-I) in the human circulation is predominantly bound to IGF-binding protein-3 (IGFBP-3) and an acidlabile subunit (ALS), forming a $140 \mathrm{kDa}$ complex. In this form IGF-I has a half-life of many hours (Guler et al. 1989), whereas when it is in the 'free' form or in binary complexes with IGFBPs, the half-life is a few minutes (Guler et al. 1989, Lewitt et al. 1993b). Human IGFBP-5 is also able to form this complex with IGF-I and ALS (Twigg \& Baxter 1998), but represents a minor proportion of IGF-I in the circulation. One group has suggested that IGFBP-3 can form a binary complex with ALS in vitro (Lee \& Rechler 1995) and in the rat circulation in vivo (Lee et al. 1997). In adult humans approximately 50\% of ALS are not in the ternary complex (Baxter 1990, Khosravi et al. 1997) and there is indirect evidence that this is true also in the rat (Lewitt et al. 1993a, Baxter \& Dai 1994, Lee et al. 1997). In rat liver cells, growth hormone (GH) stimulates transcription of ALS (Ooi et al. 1997) while cAMP (Delhanty \& Baxter 1998), dexamethasone (Dai et al. 1994) and epidermal growth factor (Dai et al. 1994) inhibit ALS synthesis and secretion.

IGF-I concentrations are decreased in diabetes mellitus in humans (Bach \& Rechler 1992) and rats (Lewitt et al. 1993a). IGFBP-3 and ALS concentrations also decrease in the diabetic state in human (Baxter \& Martin 1986) and rat (Dai \& Baxter 1994, Frystyk \& Baxter 1998) studies. Diabetes mellitus is a common clinical problem in cats. It is characterised by insulin resistance and impaired insulin secretion and, similar to human diabetes, can be insulin-dependent or noninsulin-dependent in type (Lutz \& Rand 1995). In contrast to human diabetes, we have observed that circulating IGF-I levels are often elevated in cats in the 
absence of any clinical features of acromegaly (D B Church, unpublished observation). The aim of this study was to determine the IGF-I concentrations and IGFBP profile in the serum of normal and diabetic cats.

\section{Materials and Methods}

\section{Samples}

Serum from eight diabetic cats (age range 6-18 years) was obtained from the University Veterinary Centre, Sydney. None of the study group had clinical features of acromegaly. Three had had computerised tomography scanning, which showed no pituitary tumour. Three animals had a past history of thyrotoxicosis but were not thyrotoxic at the time of study. For comparison serum was collected from eight normal cats (age range 5-14 years).

\section{IGF assays}

After acid-ethanol extraction, total IGF-I concentrations were measured in cat serum by RIA using human IGF-I standard, anti-human IGF-I antibody and human IGF-I tracer, as previously described (Church et al. 1994). It is well documented that IGFBPs potentially interfere with IGF in radioligand assays and therefore recombinant human des(1-3)-IGF-I (GroPep, Adelaide, Australia) was used to prepare tracer for duplicate assays. All serum samples were analysed in both assays. In addition, samples from four normal and four diabetic cats were applied at $\mathrm{pH}$ $2 \cdot 8$ to an HPLC column (Protein-Pak 125, Waters/ Millipore, Lane Cove, Australia) in order to separate IGFs from IGFBPs before assay.

\section{SDS-PAGE and electroblotting}

Electrophoresis was carried out on 12\% SDSpolyacrylamide gels $(5 \mathrm{~cm} \times 8 \mathrm{~cm} \times 1.5 \mathrm{~mm})$. Samples were prepared by the addition of sample buffer to final concentrations of $15.5 \mathrm{mmol} / \mathrm{l}$ Tris $-\mathrm{HCl}, 3 \%$ SDS, $10 \%$ glycerol and $0.02 \%$ bromophenol blue, $\mathrm{pH} 6.8$, and boiled for $5 \mathrm{~min}$. After electoblotting onto Hybond-ECL (Amersham Pharmacia, Biotech, Uppsala, Sweden), IGFBPs were detected by incubating with biotinylated IGF-II and then by enhanced chemiluminescence after the method described by Op De Beeck et al. (1997). In the case of the samples first separated on Superose chromatography (see below), the fractions were dialysed to remove salt and lyophilised before being taken up in sample buffer and subjected to SDS-PAGE.

\section{Size-separation chromatography}

Sera were size-fractionated under neutral conditions using methodology similar to that previously described (Gargosky et al. 1991). Serum samples $(25 \mu \mathrm{l})$ were

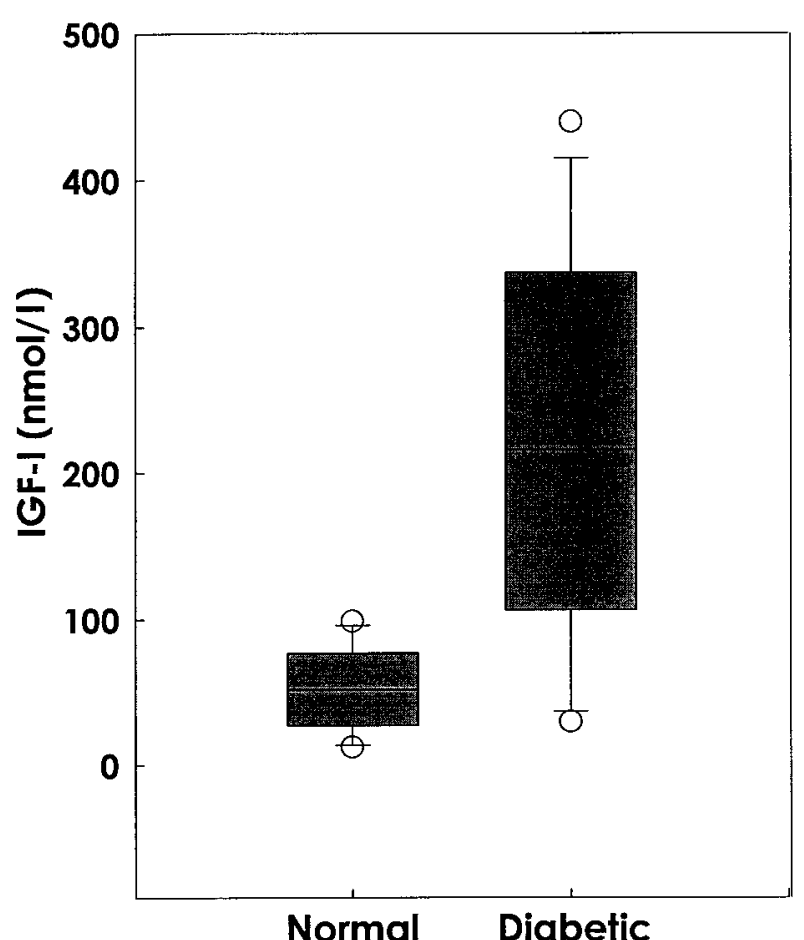

Figure 1 IGF-I concentrations in normal and diabetic cats. IGF-I was measured on acid-ethanol extracted serum samples by RIA using des(1-3)-IGF-I as tracer, as outlined in the Materials and Methods. The results for eight normal and eight diabetic cats are represented as a box plot showing the median, the 10th and 90th percentiles and the standard error of the mean. Outliers are shown as $\bigcirc$. The values for diabetic cats were significantly higher than those for normal animals $(P<0 \cdot 01)$.

incubated for $16 \mathrm{~h}$ at $4{ }^{\circ} \mathrm{C}$ with 50000 c.p.m. ${ }^{125} \mathrm{I}-\mathrm{IGF}-\mathrm{II}$ in a final volume of $100 \mu \mathrm{l}$ in $50 \mathrm{mmol} / 1$ sodium phosphate, $0.15 \mathrm{~mol} / 1$ sodium chloride, and $0.02 \%$ sodium azide, $\mathrm{pH}$ 6.5. Samples were then size-fractionated on a Superose 12 fast protein liquid chromatography (FPLC) column (Pharmacia, Uppsala, Sweden), calibrated as described previously (Baxter 1988), and run at $1 \mathrm{ml} / \mathrm{min}$. Fractions of $0.5 \mathrm{ml}$ were collected and their radioactivity counted using a $\gamma$-counter. Fractions 22-24 represent approximately $140 \mathrm{kDa}$, fractions $26-28,30-50 \mathrm{kDa}$ and fractions $32-34$, approximately $7 \mathrm{kDa}$ (free ${ }^{125} \mathrm{I}-\mathrm{IGF}-\mathrm{II}$ ).

In some experiments serum was first separated in the absence of tracer. For these studies $50 \mu \mathrm{l}$ serum were applied to the Superose 12 column in a final volume of $100 \mu \mathrm{l}$ with FPLC buffer. Samples were separated at physiological $\mathrm{pH}$ and collected as described in the preceding paragraph, and then subjected to ligand-binding assay as described below or SDS-PAGE as described above.

\section{Ligand-binding assays}

Serum samples were size-fractionated as described above and then $250 \mu \mathrm{l}$ were incubated with 20000 c.p.m. 


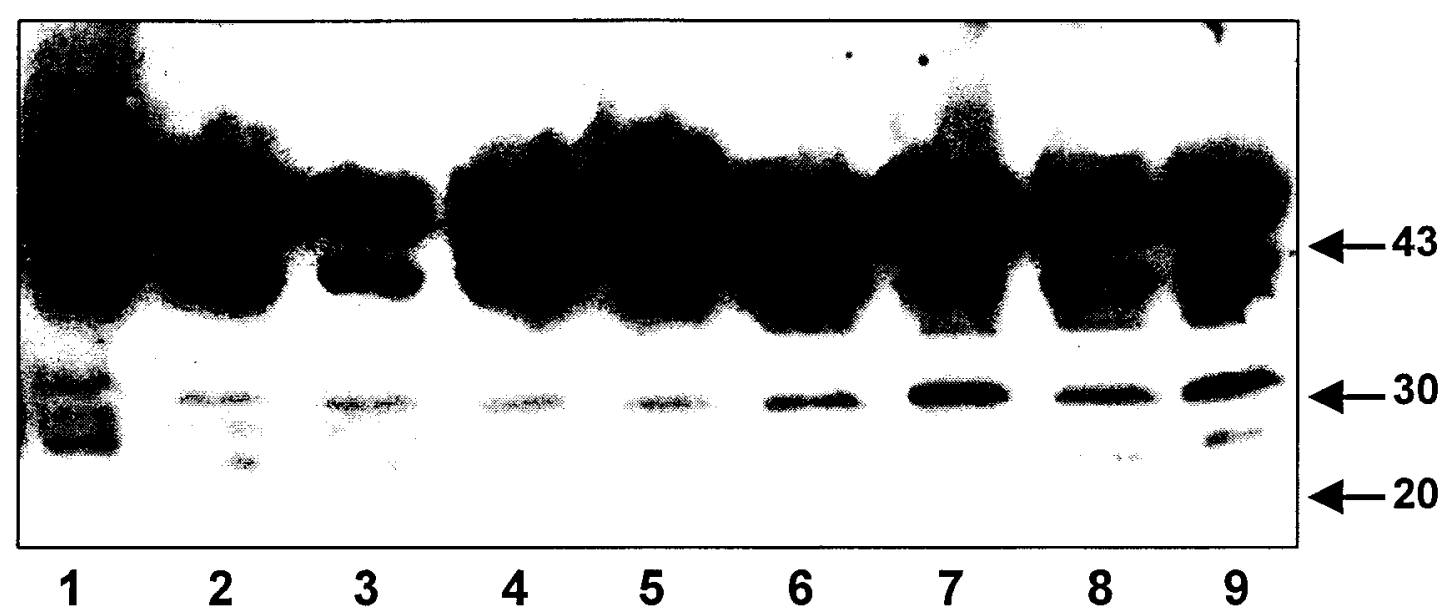

Figure 2 SDS-PAGE of IGFBPs in normal and diabetic cats. Serum samples, $0.5 \mu$, were subjected to gel electrophoresis as outlined in the Materials and Methods. Lanes 1, 3, 5, 7 and 9 are samples from diabetic cats and lanes 2, 4, 6 and 8 are normal cat samples. Molecular mass markers, run in an adjacent lane, are indicated in kDa by the arrows.

${ }^{125} \mathrm{I}-\mathrm{IGF}-\mathrm{I}$ or $-\mathrm{II}$, added in $50 \mu \mathrm{l} 0.05 \mathrm{~mol} / 1$ sodium phosphate, $1.5 \% \mathrm{BSA}, \mathrm{pH} 6.5$ for $16 \mathrm{~h}$ at $22{ }^{\circ} \mathrm{C}$. The free tracer was then separated by precipitation with charcoal. In brief $1 \mathrm{ml}$ ice cold 1\% charcoal, 1.5\% BSA was added and, after a $10 \mathrm{~min}$ incubation at $4{ }^{\circ} \mathrm{C}$, centrifuged for $15 \mathrm{~min}$ at $1500 \mathrm{~g}$. Radioiodine in half of the supernatant was counted in a $\gamma$-counter and the results multiplied by 2 and expressed as a percentage of total counts after correction for non-specific binding ( $<10 \%$ of total for both IGF-I and -II).

\section{Statistics}

Comparisons between normal and diabetic groups were made by $t$-test or by Mann-Whitney rank sum test as appropriate, and correlations were by Spearman rank order correlation (SigmaStat; Jandel Scientific Software, San Rafael, CA, USA).

\section{Results}

The IGF-I concentrations were measured by RIA using a human standard. Values were similar when des(1-3)IGF-I was used as the tracer and the displacement curves for cat serum and the human standard were parallel (data not shown). The concentrations of IGF-I in normal and diabetic cats are shown in Fig. 1, here determined using truncated IGF-I as tracer. Concentrations were 4-fold higher in the diabetic animals $(P<0 \cdot 01)$. Similar results were obtained using intact IGF-I as tracer. The lack of interference of IGFBPs in the assay was confirmed by HPLC separation of normal and diabetic cat serum $(n=4$; data not shown).
We determined the molecular size distribution of IGFBPs in the serum of normal and diabetic cats by SDS-PAGE and by Superose 12 chromatography. Figure 2 shows a Western blot using biotinylated IGF-II as ligand. After SDS-PAGE, cat serum contains a doublet of approximately $45 \mathrm{kDa}$, consistent with IGFBP-3, and a number of $25-35 \mathrm{kDa}$ forms. There were no qualitative or quantitative differences apparent between the normal and diabetic samples under these, denaturing, conditions and co-incubation of samples from normal and diabetic cats showed an additive effect (data not shown), suggesting the absence of circulating protease activity.

There were clear differences, however, between control and diabetic serum when samples were sizefractionated at physiological $\mathrm{pH}$ on a Superose 12 column. After overnight incubation with radiolabelled IGF-II, $26 \pm 2 \%$ (s.E.M) of ${ }^{125}$ I-IGF-II were in a $140 \mathrm{kDa}$ form in serum from normal animals compared with $48 \pm 5 \%$ in diabetic animals $(P<0 \cdot 001$; Fig. 3). The percentage at $30-50 \mathrm{kDa}$ was $38 \pm 3 \%$ in normal animals and $12 \pm 2 \%$ in diabetic animals $(P<0 \cdot 001)$. The percentage at $140 \mathrm{kDa}$ correlated with IGF-I concentrations $(r=0.571 ; P<0 \cdot 05)$.

In order to confirm the observed increase in the $140 \mathrm{kDa}$ form, we first separated the serum under neutral conditions on Superose 12 chromatography and then performed ligand-binding assays with ${ }^{125} \mathrm{I}-\mathrm{IGF}-\mathrm{II}$, or lyophilised the samples and subjected them to Western ligand blotting with IGF-II tracer. Figure 4A shows that there was more ${ }^{125}$ I-IGF-II binding at $140 \mathrm{kDa}$ in diabetic samples than in normal cat serum. Under these conditions there was no difference in the binding at $30-50 \mathrm{kDa}$. When samples were acidified for $1 \mathrm{~h}$ at $37^{\circ} \mathrm{C}$ and then neutralised, before size-separation, all high molecular mass 


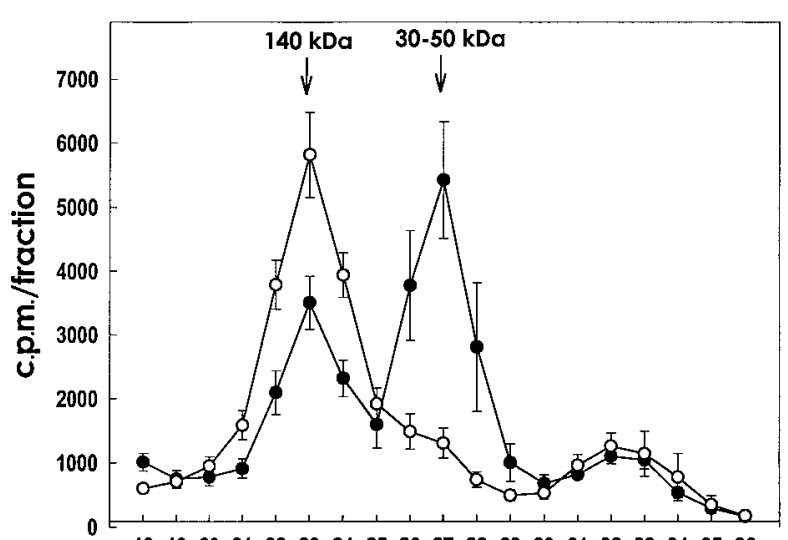

$\begin{array}{lllllllllllllllllll}18 & 19 & 20 & 21 & 22 & 23 & 24 & 25 & 26 & 27 & 28 & 29 & 30 & 31 & 32 & 33 & 34 & 35 & 36\end{array}$

Superose fraction $(500 \mu \mathrm{l})$

Figure 3 Size-distribution of IGFBPs in the cat circulation. Serum samples from eight normal $(\mathbf{)})$ and eight diabetic $(\bigcirc)$ cats were incubated for $16 \mathrm{~h}$ at $4{ }^{\circ} \mathrm{C}$ with ${ }^{125}$ I-IGF-II and then fractionated on a Superose 12 size-exclusion column under neutral conditions, as outlined in the Materials and Methods. The approximate molecular masses of the major peaks are indicated. The values are the means \pm S.E.M.

binding (140 kDa and greater) was abolished (data not shown). Figure 4B shows that, when Superose fractions are separated on SDS-PAGE, the $140 \mathrm{kDa}$ peak fractions appear as a $45 \mathrm{kDa}$ doublet. When the ligand-binding assay was performed with ${ }^{125}$ I-IGF-I (Fig. 5) an increase in the $140 \mathrm{kDa}$ peak and a decrease in the $30-50 \mathrm{kDa}$ peak were also observed in diabetic animals. Binding at a molecular mass greater than $140 \mathrm{kDa}$, which was observed for ${ }^{125}$ I-IGF-II, was not observed when ${ }^{125}$ I-IGF-I was used as the ligand.

We speculated that, in contrast to the situation in humans (Baxter 1990, Khosravi et al. 1997) and rats (Lewitt et al. 1993a, Baxter \& Dai 1994, Lee et al. 1997), in which ALS circulates in excess, low ALS concentrations in the circulation of normal cats might limit formation of the IGFBP-3 ternary complex. We therefore determined the IGFBP size-distribution in the presence of added 'free' ALS. We did this by co-incubation of normal cat serum with normal human serum, which contains 'excess' ALS. Human serum and normal cat serum (12.5 $\mu$ l of each) were incubated overnight in the presence of ${ }^{125} \mathrm{I}$-IGF-II. Figure $6 \mathrm{~A}$ demonstrates a shift from $17 \pm 5 \%$ in the $140 \mathrm{kDa}$ form to $48 \pm 1 \%(P<0 \cdot 05)$, similar to that present in pooled human serum alone $(48 \%)$. In order to determine whether diabetic cat serum contained excess ALS, $12 \cdot 5 \mu \mathrm{l}$ diabetic serum were incubated with $12 \cdot 5 \mu \mathrm{l}$ normal cat serum in the presence of ${ }^{125} \mathrm{I}$-IGF-II. As shown in Fig. 6B, in three experiments conducted under these conditions, there was a shift from $20 \pm 1 \%$ in the $140 \mathrm{kDa}$ form to $52 \pm 2 \% \quad(P<0 \cdot 05)$, similar to that present in diabetic serum alone $(48 \pm 7 \%)$.
A

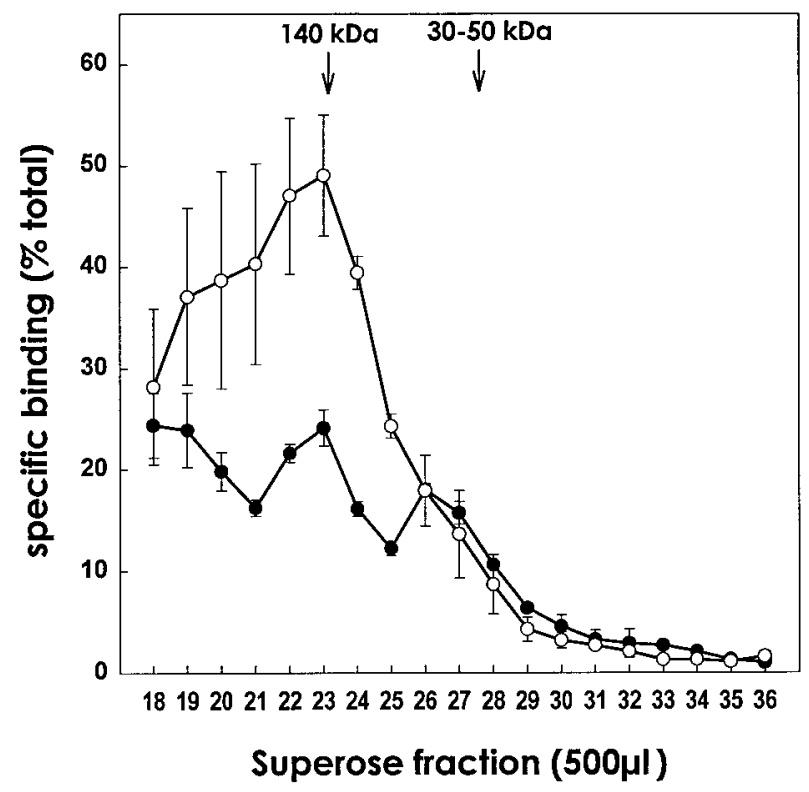

B

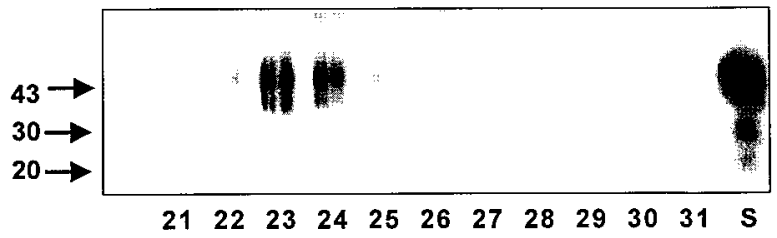

Figure 4 (A) IGF-II ligand-binding assay of IGFBPs in the cat circulation. Serum samples from eight normal $(\mathbf{O})$ and eight diabetic $(\bigcirc)$ cats were fractionated on a Superose 12 sizeexclusion column under neutral conditions. Each fraction was subjected to ${ }^{125}$ I-IGF-II ligand binding with charcoal precipitation, as outlined in the Materials and Methods. The approximate molecular masses of the major peaks are indicated. The values are the means \pm S.E.M. (B) SDS-PAGE of IGFBPs in the cat circulation after size-separation chromatography. A representative gel from a diabetic cat sample is shown. The lanes represent fraction numbers after Superose 12 chromatography of serum. The samples were dialysed and lyophilised prior to electrophoresis. Serum, $0 \cdot 5 \mu \mathrm{l}$, was run in the lane marked S. Molecular mass markers, run in an adjacent lane, are indicated in kDa by the arrows.

\section{Discussion}

In this paper we have shown that, in contrast to human serum, normal cat serum appears to have limited IGFBP-3 ternary complex formation. In feline diabetes, the amount of ternary complex increases substantially, and is associated with 4-fold higher serum IGF-I concentrations compared with normal cats. The values were derived in a human RIA and so the absolute values could not be determined in 


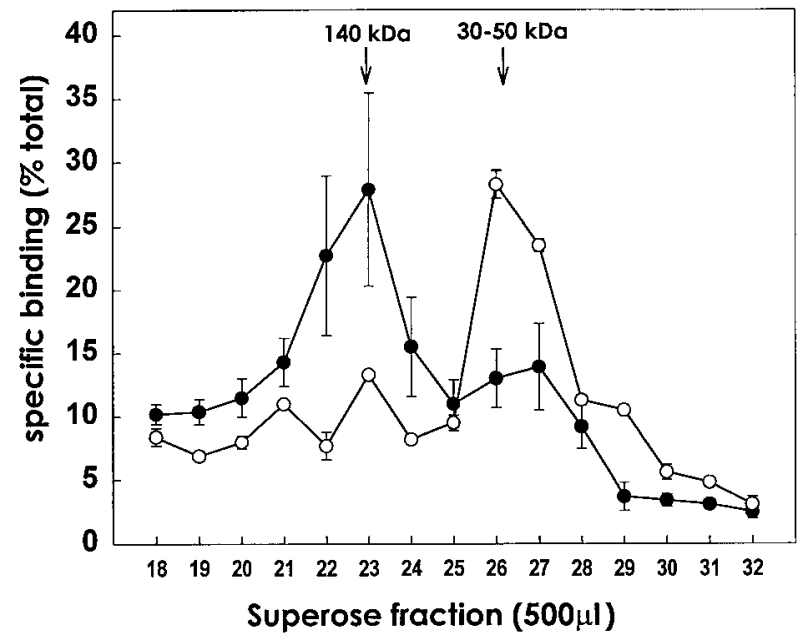

Figure 5 IGF-I ligand-binding assay of IGFBPs in the cat circulation. Serum samples from three normal $(\mathbf{0})$ and three diabetic $(\bigcirc)$ cats were fractionated on a Superose 12 sizeexclusion column under neutral conditions. Each fraction was determined by ${ }^{125}$ I-IGF-I ligand binding with charcoal precipitation, as outlined in the Materials and Methods. The approximate molecular masses of the major peaks are indicated. The values are the means \pm S.E.M.

the absence of a cat IGF-I standard. However, the possibility that normal cat serum is low in IGF-I relative to other species could explain why the adipogenic potential of cat serum has previously been observed to be low (Kuri-Harcuch \& Green 1978, Guller et al. 1989).

We determined the IGFBP species in cat serum in several ways. Methods in which the distribution of radioactivity is determined after an overnight incubation in vitro may be difficult to interpret because of the presence of several 20-35 kDa IGFBPs, which may each have different IGF affinities and may be differentially influenced by diabetes. For example, a decrease of a $30 \mathrm{kDa}$ IGFBP with a high very high affinity for IGF-II might account for a shift to IGFBP-3 in the ternary complex in diabetes. Therefore we also looked at the IGFBP profile after size-separation of serum and confirmed an increase in the $140 \mathrm{kDa}$ form and the presence of a $45 \mathrm{kDa}$ doublet in those chromatography fractions, consistent with IGFBP-3. In the presence of labelled IGF-II, very high molecular mass binding $(>140 \mathrm{kDa})$ was also demonstrated. This was not present when IGF-I was used as the ligand, raising the possibility that this represents a soluble form of the IGF-II/mannose 6-phosphate receptor, which has been detected in human serum and urine (Kiess et al. 1987, Causin et al. 1988, Gelato et al. 1988, 1989, Valenzano et al. 1995). The serum IGF-II/mannose 6-phosphate receptor increases in pregnant diabetic women (Gelato et al. 1993) and is stimulated by insulin injection in rats (Clairmont \& Czech 1990). Whether there is an increase in feline diabetes will require further study.
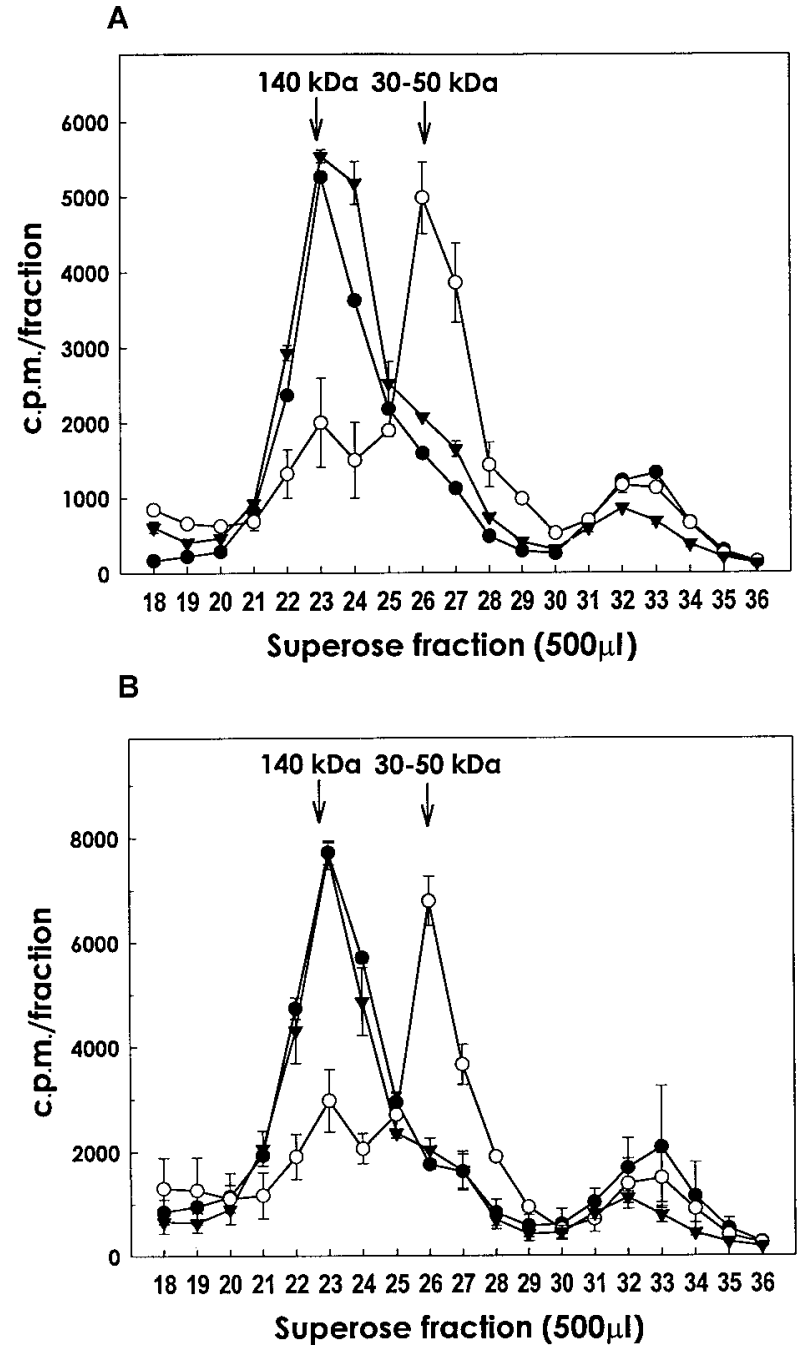

Figure 6 (A) Size-distribution of IGFBPs after co-incubation of normal cat serum and pooled normal human serum. Serum samples, $12 \cdot 5 \mu \mathrm{l}$, from three normal cats $(\bigcirc)$ and a pool from several healthy human volunteers $(\bullet)$, were incubated overnight in the presence of ${ }^{125}$ I-IGF-II, alone, and in combination $(\boldsymbol{\nabla})$. B) Size-distribution of IGFBPs after co-incubation of normal and diabetic cat serum. Serum samples, $12.5 \mu \mathrm{l}$, from three normal $(\bigcirc)$ and three diabetic $(-)$ cats were incubated overnight alone, and in combination $(\boldsymbol{\nabla})$, in the presence of ${ }^{125}$ I-IGF-II. The samples in both panels were fractionated after incubation on a Superose 12 size-exclusion column under neutral conditions, as outlined in the Materials and Methods. The approximate molecular masses of the major peaks are indicated. The values are the means \pm S.E.M.

There were no apparent differences between normal and diabetic profiles on SDS-PAGE and in particular there was no increase in the intensity of the $45 \mathrm{kDa}$ doublet. This was surprising in view of the clear increase in the levels of IGF-I and ternary complex in diabetic cats. A likely explanation for this phenomenon is that a proportion of IGFBP-3 circulates 'free' in normal cats and is available 
to participate in ternary complex formation both in vitro and in vivo, in diabetes.

These studies suggest that ALS does not circulate in excess of the ternary complex in normal cats. When incubated in vitro with normal human serum, which contains substantial concentrations of 'free' ALS, there was a shift of the labelled IGF-II to a pattern in which $140 \mathrm{kDa}$ binding predominated. An alternative explanation for this would be that there is substantially greater affinity of the human IGF-II label for human ALS even in the presence of cat IGFBP-3. However, the pattern was identical when normal and diabetic cat serum were co-incubated. An increase in ALS in feline diabetes mellitus would contrast with the situation in humans and in rats and the mechanism of such an increase is the subject of ongoing investigation.

Our study sample was recruited from veterinary patients. Animals were not fasting and were not controlled for the time since the last meal. Three of the diabetic cats had a history of treated hyperthyroidism, which is known to be associated with impaired glucose tolerance (Hoenig et al. 1992). While we cannot exclude an effect of previous thyroid disease on the IGF axis, none was currently thyrotoxic and there was no difference between this group and the rest of the study series.

The observations we have made in this study are important for at least three reasons. First, they indicate that the use of IGF-I concentrations to screen for GH excess may be unreliable in diabetic cats. Secondly, they add to the current knowledge of ALS regulation and indicate that an important stimulator might exist in feline diabetes mellitus or that the nature of ALS regulation differs between species. Finally, they raise the possibility that the IGF system might contribute to the pathophysiology of feline diabetes mellitus. Further carefully controlled studies are required to address these issues.

\section{Acknowledgements}

The authors are grateful to Dot Lewis for her assistance in the final preparation of the manuscript.

\section{References}

Bach LA \& Rechler MM 1992 Insulin-like growth factors and diabetes. Diabetes and Metabolism Reviews 8 229-257.

Baxter RC 1988 Characterization of the acid-labile subunit of the growth hormone-dependent insulin-like growth factor binding protein complex. Journal of Clinical Endocrinology and Metabolism 67 265-272.

Baxter RC 1990 Circulating levels and molecular distribution of the acid-labile $(\alpha)$ subunit of the high molecular weight insulin-like growth factor-binding protein complex. Journal of Clinical Endocrinology and Metabolism 70 1347-1353.

Baxter RC \& Dai J 1994 Purification and characterization of the acidlabile subunit of rat serum insulin-like growth factor binding protein complex. Endocrinology 134 848-852.
Baxter RC \& Martin JL 1986 Radioimmunoassay of growth hormonedependent insulin-like growth factor binding protein in human plasma. Journal of Clinical Investigation 78 1504-1512.

Causin C, Waheed A, Braulke T, Junghans U, Maly P, Humbel R \& Von Figura K 1988 Mannose 6-phosphate/insulin-like growth factor II-binding proteins in human serum and urine. Biochemical Journal 252 795-799.

Church DB, Watson ADJ, Emslie DJ, Middleton D, Tan K \& Wong D 1994 Effects of proligestone and megestrol on plasma adrenocorticotrophic hormone, insulin and insulin-like growth factor-I concentrations in cats. Research in Veterinary Science 56 175-178.

Clairmont KB \& Czech MP 1990 Insulin injection increases the levels of serum receptors for transferrin and insulin-like growth factor-II/ mannose-6-phosphate in intact rats. Endocrinology 127 1568-1573.

Dai J \& Baxter RC 1994 Regulation in vivo of the acid-labile subunit of the rat serum insulin-like growth factor-binding protein complex. Endocrinology 135 2335-2341.

Dai J, Scott CD \& Baxter RC 1994 Regulation of the acid-labile subunit of the insulin-like growth factor complex in cultured rat hepatocytes. Endocrinology 135 1066-1072.

Delhanty PJD \& Baxter RC 1998 The regulation of acid-labile subunit gene expression and secretion by cyclic adenosine $3^{\prime}, 5^{\prime}$ monophosphate. Endocrinology 139 260-265.

Frystyk J \& Baxter RC 1998 Competitive binding assay for determination of rat insulin-like growth factor binding protein-3. Endocrinology 139 1454-1457.

Gargosky SE, Owens PC, Walton PE, Owens JA, Robinson JS, Wallace JC \& Ballard FJ 1991 Most of the circulating insulin-like growth factors-I and -II are present in the $150 \mathrm{kDa}$ complex during human pregnancy. Journal of Endocrinology 131 491-497.

Gelato MC, Kiess W, Lee L, Malozowski S, Rechler MM \& Nissley P 1988 The insulin-like growth factor II/mannose-6-phosphate receptor is present in monkey serum. Journal of Clinical Endocrinology and Metabolism 67 669-675.

Gelato MC, Rutherford C, Stark RI \& Daniel SS 1989 The insulinlike growth factor II/mannose-6-phosphate receptor is present in fetal and maternal sheep serum. Endocrinology 124 2935-2943.

Gelato MC, Rutherford C, Sanroman G, Shmoys S \& Monheit A 1993 The serum insulin-like growth factor-II/mannose-6-phosphate receptor in normal and diabetic pregnancy. Metabolism 42 10311038.

Guler H-P, Zapf J, Schmid C \& Froesch ER 1989 Insulin-like growth factors I and II in healthy man. Estimations of half lives and production rates. Acta Endocrinologica 121 753-758.

Guller S, Sonenberg M \& Corin RE 1989 Expression of growth hormone-independent adipogenensis by a $3 \mathrm{~T} 3$ cell variant. Endocrinology 124 325-332.

Hoenig M, Peterson ME \& Ferguson DC 1992 Glucose tolerance and insulin secretion in spontaneously hyperthyroid cats. Research in Veterinary Science 53 338-341.

Khosravi MJ, Diamandi A, Mistry J, Krishna GH \& Khare A 1997 Acid-labile subunit of human insulin-like growth factor-binding protein complex: measurement, molecular, and clinical evaluation. Journal of Clinical Endocrinology and Metabolism 82 3944-3951.

Kiess W, Greenstein LA, White RM, Lee L, Rechler MM \& Nissley SP 1987 Type II insulin-like growth factor receptor is present in rat serum. PNAS 84 7720-7724.

Kuri-Harcuch W \& Green H 1978 Adipose conversion of 3T3 cells depends on a serum factor. PNAS 75 6107-6109.

Lee CY \& Rechler MM 1995 Purified rat acid-labile subunit and recombinant human insulin-like growth factor (IGF)-binding protein-3 can form a 150-kilodalton binary complex in vitro in the absence of IGFs. Endocrinology 136 4982-4989.

Lee CY, Wu HB, Suh DS \& Rechler MM 1997 Insulin-like growth factor-I (IGF-I) concentration in 150-kilodalton complexes containing human IGF-binding protein-3 (hIGFBP-3) after 
intravenous injection of adult rats with hIGFBP-3. Endocrinology 138 1649-1657.

Lewitt MS, Saunders H \& Baxter RC 1993a Bioavailability of insulinlike growth factors (IGFs) in rats determined by the molecular distribution of human IGF-binding protein-3. Endocrinology 133 1797-1802.

Lewitt MS, Saunders H, Cooney GJ \& Baxter RC 1993b Effect of human insulin-like growth factor-binding protein-1 on the half-life and action of administered insulin-like growth factor-I in rats. Journal of Endocrinology 136 253-260.

Lutz TA \& Rand JS 1995 Pathogenesis of feline diabetes mellitus. Veterinary Clinics of North America 25 527-552.

Ooi GT, Cohen FJ, Tseng LY-H, Rechler MM \& Boisclair YR 1997 Growth hormone stimulates transcription of the gene encoding the acid-labile subunit (ALS) of the circulating insulin-like growth factor-binding protein complex and ALS promoter activity in rat liver. Molecular Endocrinology 11 997-1007.
Op De Beeck L, Verlooy JEA, Van Buul-Offers SC \& Du Caju MVL 1997 Detection of serum insulin-like growth factor binding proteins on Western ligand blots by biotinylated IGF and enhanced chemiluminescence. Journal of Endocrinology 154 R1-R5.

Twigg SM \& Baxter RC 1998 Insulin-like growth factor (IGF)binding protein 5 forms an alternative ternary complex with IGFs and the acid-labile subunit. Journal of Biological Chemistry 273 6074-6079.

Valenzano KJ, Remmler J \& Lobel P 1995 Soluble insulin-like growth factor II/mannose 6-phosphate receptor carries multiple high molecular weight forms of insulin-like growth factor II in fetal bovine serum. Journal of Biological Chemistry 270 16441-16448.

Received 20 October 1999

Accepted 14 March 2000 